Article

\title{
Inclusion of concentrate and growth promoters' additives in sheep diets on intake, digestibility, degradability, ruminal variables and nitrogen balance
}

\author{
Marcelo Vedovatto ${ }^{a}$ \\ Camila da Silva Pereira ${ }^{a}$ \\ João Artêmio Marin Beltrame ${ }^{\mathrm{a}}$ \\ Ibrahin Miranda Cortada Neto ${ }^{a}$ \\ Anderson Luiz de Lucca Bento ${ }^{\text {a }}$ \\ Gabriella de Oliveira Dalla Martha ${ }^{\text {a }}$ \\ Maria da Graça Morais a \\ Gumercindo Loriano Franco ${ }^{a *}$
}

anniversidade Federal de Mato Grosso do Sul, Faculdade de Medicina Veterinária e Zootecnia. Campo Grande/MS, Brazil.

* Corresponding author: gumercindo.franco@ufms.br

\begin{abstract}
:
This study evaluated the inclusion of concentrate and monensin, salinomycin and flavomycin in sheep diets on intake, digestibility, in situ degradability, ruminal variables and nitrogen balance. Five sheep in a latin square received the treatments: HAY (hay only), CONT (hay + concentrate), MON (hay + concentrate + monensin), SALI (hay + concentrate + salinomycin), and FLAV (hay + concentrate + flavomycin). Hay was offered ad libitum, concentrate, $20 \mathrm{~g} \mathrm{~kg}^{-1}$ of body weight (BW), and additives, $0.75 \mathrm{mg}$ $\mathrm{kg}^{-1}$ of BW. The treatments with the concentrate (CONT, MON, SALI and FLAV) showed increased $(P \leq 0.05)$ on intake, digestibility, total VFA, propionate and butyrate proportions, $\mathrm{N}-\mathrm{NH}_{3}$, and nitrogen balance, and decreased $(P \leq 0.05) \mathrm{DM}$ and NDF degradability, acetate proportion, acetate:propionate ratio, and rumen $\mathrm{pH}$ compared to the HAY. The comparison between the outcome effects from additives with the CONT
\end{abstract}


showed that the acetate proportion and acetate:propionate ratio was only reduced by MON $(P \leq 0.05)$. MON and SALI increased $(P \leq 0.05)$ the propionate proportion. The proportion of butyrate was increased with the inclusion of FLAV and reduced with MON 8and SALI. Only MON reduced the production of $\mathrm{N}^{-N_{3}}(P \leq 0.05)$. Other variables showed no effects from additives $(P>0.05)$ in relation to the CONT. The inclusion of the concentrate in sheep diets caused alterations on intake, digestibility, ruminal variables (VFA, $\mathrm{pH}$, and $\mathrm{N}-\mathrm{NH}_{3}$ ) and nitrogen balance. However, the additives only altered the ruminal variables (VFA and $\mathrm{N}-\mathrm{NH}_{3}$ ) and the greatest effects were observed with MON.

Key words: Bambermycin, Flavomycin, Monensin, Ruminants, Salinomycin.

Received: 11/07/2018

Accepted: 06/02/2019

\section{Introduction}

The evolution of the knowledge of the nutritional requirements of sheep, to obtain high productive performance, has led to the use of feedlot diets, that are formulated with high levels of concentrate, and small levels of roughage ingredients ${ }^{(1)}$. The provision of concentrates affects ruminal fermentation ${ }^{(2)}$ and, high levels of inclusion have been associated with the occurrence of nutritional disturbances, mainly acidosis ${ }^{(3)}$. Growth promoters additives, have shown the potential to modulate ruminal fermentation, reflecting in high productive performance, in addition to reducing risks of nutritional disturbances.

The class of ionophores is most commonly used as growth promoters, for animals of zootechnical interest. Although more than 120 antibiotics belong to this class, monensin is probably the most researched and used additive in ruminant diets ${ }^{(4)}$. Similarly, salinomycin also belongs to the ionophore class, and is widely researched and used. According to Edwards et $a l^{(5)}$ other non-ionophore antibiotics, such as flavomycin, have proved to be beneficial in altering ruminal fermentation and have been used as an additive. The beneficial alteration caused by ionophores in the rumen occurs because they act on Gram-positive bacteria, fungi and protozoa, and thus enable better conditions for Gramnegative bacteria to develop ${ }^{(6)}$. These alterations in the rumen's microbiology reflect in lower production of methane, ammonia, and acetic and butyric acids. Propionic acid production is increased, so there is an increase in energy efficiency and this reflects increasing the weight gain or feed efficiency of ruminants ${ }^{(7)}$. 
Flavomycin has a mechanism of action different from ionophores, and its microorganism selectivity is different. It does not act on all species of Gram-positive bacteria, and has no effect on fungi and protozoa ${ }^{(5)}$. This additive has been shown as efficient for increasing the weight gain or feed efficiency in ruminants ${ }^{(8,9)}$, however, its effect on ruminal fermentation is not fully understood.

Thus, this study evaluated the effects of the inclusion of concentrate, and compared the effects of the addition of monensin, salinomycin and flavomycin in sheep diets on intake, digestibility, in situ degradability, ruminal variables ( $\mathrm{pH}, \mathrm{N}-\mathrm{NH}_{3}$ and VFA), and nitrogen balance.

\section{Material and methods}

\section{Experimental site and animal care}

The experiment was conducted at Animal Metabolism Laboratory of Faculdade de Medicina Veterinária e Zootecnia, Universidade Federal de Mato Grosso do Sul (Campo Grande, Mato Grosso do Sul, Brazil). The experiment was conducted according to the institutional Ethics Committee on Animal Use under case no.: 577/2013.

\section{Animals, management and treatments}

Five male sheep ( $1 / 2$ Suffolk $+1 / 2$ Santa Ines) with a permanent cannula inserted in the rumen and, initial mean body weight (BW) of $46.50 \pm 5.45 \mathrm{~kg}$ were used in the study. The sheep were housed in special cages for metabolism studies that are suitable for in vivo digestibility assays. These cages had a slatted wood floor and contained a feeder, drinking fountain, and a galvanized steel supplement for urine collection. The cages were housed in a covered shed with good ventilation.

The animals were fed with chopped Coast-cross hay (Cynodon dactylon (L.) Pers.) and concentrate (Table 1). The concentrate formulation contained fine ground corn (700 g $\left.\mathrm{kg}^{-1}\right)$, soybean meal $\left(260 \mathrm{~g} \mathrm{~kg}^{-1}\right)$ and mineral premix $\left(40 \mathrm{~g} \mathrm{~kg}^{-1}\right)$. The experimental treatments included growth promoters additives in the concentrate as follows: HAY (hay only); CONT (hay + concentrate); MON (hay + concentrate + monensin), SALI (hay + concentrate + salinomycin), and FLAV (hay + concentrate + flavomycin). Hay was offered ad libitum, concentrate in the amount of $20 \mathrm{~g} \mathrm{~kg}^{-1}$ of BW, and additives $0.75 \mathrm{mg}$ $\mathrm{kg}^{-1}$ of BW. 
Table 1: Chemical composition of the concentrate and Coast-Cross hay (Cynodon dactylon (L.) Pers.)

\begin{tabular}{|c|c|c|c|c|c|c|c|}
\hline \multirow{2}{*}{ Item } & \multirow{2}{*}{ DM $\left(\mathrm{g} \mathrm{kg}^{-1}\right)$} & \multicolumn{6}{|c|}{ Chemical composition $\left(\mathrm{g} \mathrm{kg}^{-1} \text { of } \mathrm{DM}\right)^{1}$} \\
\hline & & $\mathbf{O M}$ & $\mathbf{C P}$ & aNDFom & $\mathbf{E E}$ & NSC & Ashes \\
\hline Concentrate $^{2}$ & 870 & 904 & 188 & 214 & 24 & 479 & 96 \\
\hline Hay & 875 & 936 & 69 & 732 & 15 & 119 & 64 \\
\hline
\end{tabular}

The additives were weighed on an analytical balance and stored in microtubes until use. Hay and concentrate were provided in separate troughs. The hay and concentrate were provided in two meals a day, at 0007 and $0017 \mathrm{~h}$. Hay intake was adjusted to provide orts of $150 \mathrm{~g} \mathrm{~kg}^{-1}$. Additives were provided only with the morning meal and mixed with the concentrate. The amount of hay and concentrate met the nutritional requirements of growing sheep with an average daily gain of $250 \mathrm{~g} \mathrm{~d}^{-1(1)}$.

The experimental design was a 5 x 5 latin square. Five experimental periods of $21 \mathrm{~d}$ each were performed as $10 \mathrm{~d}$ of adaptation to treatments and $11 \mathrm{~d}$ of data collection. At each new experimental period, the animals were weighed after 16 -h solids fasting to adjust the amounts of concentrate and additive.

\section{Intake control and collection of feces and urine}

The control of daily intake of feed and water was performed between d 11 and 15 of each experimental period by weighing the amounts of feed offered and orts. Feces and urine were collected in the same period. Water intake was controlled by measuring the quantity supplied in the morning and afternoon. Orts water was measured in the drinking fountains only in the mornings. A control drinking fountain (without animal access) was also used to measure evaporation during the day in order to assess actual water intake in the experiments. A feces collecting bag was adapted to animals to allow total collection of feces. These bags were emptied daily in the morning and afternoon at the same times. Feces were weighed, homogenized, and samples equivalent to $100 \mathrm{~g} \mathrm{~kg}^{-1}$ were stored $\left(-20^{\circ} \mathrm{C}\right)$ for further analysis. Based on this information, the following parameters were evaluated: intake (offered - orts), apparent digestibility coefficients (nutrient intake excreted nutrient/nutrient intake) of DM, OM, CP, neutral detergent fiber corrected for ashes with the use of amylase (aNDFom), ethereal extract (EE), and NSC. The TDN were estimated by the formula proposed by Sniffen et $a l^{(10)}$ : TDN= digestible $\mathrm{CP}+$ digestible aNDFom $+2.25 *$ digestible EE + digestible NSC. 
In addition to the feces, urine was collected for the evaluation of nitrogen balance. Urine was collected in buckets containing $100 \mathrm{~mL}$ of sulfuric acid $\left(100 \mathrm{~mL} \mathrm{~L}^{-1}\right)$ placed in the lower part of urine collectors in the metabolic cages. These buckets were emptied daily in the morning and afternoon at the same time. Samples of $100 \mathrm{ml} \mathrm{L}^{-1}$ were collected and stored $\left(-20{ }^{\circ} \mathrm{C}\right)$. For nitrogen $(\mathrm{N})$ balance analysis, absorbed $\mathrm{N}$ was calculated by the difference between $\mathrm{N}$ intake and excreted in the feces, while the $\mathrm{N}$ retained was obtained by the difference between $\mathrm{N}$ intake and excreted in feces and urine.

\section{Measurement of in situ degradability}

The ruminal degradability of DM and NDF was determined from d 16 to 19 of each period using $5 \times 5 \mathrm{~cm}$ nylon bags with a porosity of $50 \mu \mathrm{m}$, sealed at the edges and properly identified. These bags were weighed empty, filled with $2.5 \mathrm{~g}$ of hay (ground and passed through a $2 \mathrm{~mm}$ pore sieve), and tied with a rubber band to a metal ring to keep them closed. These bags were first soaked in water for one hour and subsequently attached to a metal chain and anchor weighing approximately $100 \mathrm{~g}$. These bags were subsequently infused into the rumen via cannula at $0007 \mathrm{~h}$ (before feeding) and removed after the incubation times $(3,8,16,24,48,72$ and $96 \mathrm{~h})$. These bags were immersed in ice water immediately after removal from the rumen and washed in a washing machine for five minutes for three cycles, changing the water in each cycle. They were subsequently placed in a forced air ventilation oven at $55^{\circ} \mathrm{C}$ for $72 \mathrm{~h}$ and weighed after this period.

The DM soluble fraction from hay was determined with nylon bags with samples without incubation in the rumen. These bags were kept in water $\left(38^{\circ} \mathrm{C}\right)$ for one hour, washed in a washing machine, oven dried, and weighed. The difference between the initial and final weight was considered as the soluble fraction for each experimental period, which corresponds to the value at $0 \mathrm{~h}$ in the DM degradation curve. The soluble fraction " $\mathrm{a}$ ", insoluble fraction " $b$ ", rate of degradation "c", and effective degradability (ED) were calculated according to Ørskov and McDonald ${ }^{(11)}$ with the equation $\mathrm{ED}=\mathrm{a}+(\mathrm{bxc}) /(\mathrm{c}+$ $\mathrm{k})$, where " $\mathrm{k}$ " is the estimated rumen solids passage rate calculated as $0.02,0.05$, and 0.08 $\mathrm{h}^{-1}$ in the present study.

\section{Collection of ruminal liquid samples and $\mathrm{pH}$}

Ruminal liquid samples were collected for the determination of VFA, $\mathrm{pH}$, and $\mathrm{N}_{-} \mathrm{NH}_{3}$ from d 20 to 21 in each experimental period. The samples were collected at the end of the experimental period after removal of the nylon bags. At the collection time, samples were taken at zero hours (before supplementation) and at 2, 4, 8, 10, 12, 14, 16, 18, 20, 22 and $24 \mathrm{~h}$ after feeding in the morning and always following the same sequence among 
animals. The ruminal fluid collection was performed with the help of a metal shell inserted in a cloth diaper. An aliquot of approximately $100 \mathrm{~mL}$ of ruminal fluid was collected.

The $\mathrm{pH}$ was measured immediately after the collection of ruminal liquid using a digital potentiometer (B474; Micronal, São Paulo, SP, Brazil). The VFA analysis used four $\mathrm{mL}$ of ruminal fluid acidified with $1 \mathrm{~mL}$ of metaphosphoric acid $(25 \%)$ and stored at $-20{ }^{\circ} \mathrm{C}$. The $\mathrm{N}_{-} \mathrm{NH}_{3}$ analysis used $50 \mathrm{~mL}$ of ruminal liquid acidified with $1 \mathrm{~mL}$ of $\mathrm{H}_{2} \mathrm{SO}_{4}(50 \%)$ and stored at $-20^{\circ} \mathrm{C}$.

\section{Chemical analysis}

The analysis of the chemical composition of feeds, orts, and feces was conducted according to $\mathrm{AOAC}^{(12)}$ as follows: DM - method 967,03; CP- method 981,10; Ashes method 942,05; and EE - method 920,29. The NDF content was analyzed in a Tecnal TE149® fiber analyzer (Tecnal, Piracicaba, SP, Brazil) using 5 X $5 \mathrm{~cm}$ non-woven fabric (NWF) bags with $100 \mu \mathrm{m}$ porosity. To these were added $0.5 \mathrm{~g}$ of sample (feed or faeces) and followed for neutral detergent analysis according to the methodology of Van Soest et $a l^{(13)}$ without sodium sulfite and using thermostable amylase (Termamyl $120 \mathrm{~L}$ Novozymes A/S, Bagsvaerd, Denmark). Subsequently, the NDF was corrected for ashes and the aNDFom content was calculated. The same procedure used for the NDF was used to analyze the material resulting from the in situ ruminal degradation but without the use of amylase and correction for ashes. The NSC content was calculated as proposed by Sniffen et $a l^{(10)}$ with the equation: $\mathrm{NSC}=100-(\mathrm{CP}+$ ashes + aNDFom $+\mathrm{EE})$.

The $\mathrm{N}-\mathrm{NH}_{3}$ content analysis used the supernatant of ruminal liquid samples thawed at 4 ${ }^{\circ} \mathrm{C}$ and distillation with $2 \mathrm{~N} \mathrm{KOH}$ according to Ribeiro et $a l^{(14)}$. The concentration of VFAs was determined by gas chromatography (Shimadzu GC-2010, Kyoto, Japan) according to the methodology described by Erwin et al ${ }^{(15)}$.

\section{Statistical analyses}

Statistical analyses were performed using the SAS statistical software (SAS Inst., Inc., Cary, NC). The data of intake, apparent digestibility and nitrogen balance were analyzed using ANOVA with a 5 x 5 latin square design. The statistical model used was:

$$
Y i j k=\mu+T i+P j+A k+e i j k
$$


Where:

Yijk $=$ observation of the effect of treatment $i$ in period $j$, of animal $k$, where $\mu$ is the overall mean, $T i=$ effect of treatment $i$, where $i=1$ (HAY), 2 (CONT), 3 (MON), 4 (SALI), and 5 (FLAV);

$P j=$ effect of period $j(j=5$ periods $)$;

$A k=$ effect of animal $k(k=5$ animals $)$, and eijk = random error associated with each observation.

The model for the in situ degradation rate included the experimental treatment, incubation time, animal, period, and treatment $\times$ time. The experimental design was the latin square with subdivided plots for the ruminal variables data (VFA, $\mathrm{pH}$, and $\mathrm{N}-\mathrm{NH}_{3}$ ), where the plots were the treatments and subplots were ruminal liquid samples. The statistical model included treatment effects, sampling times, animal, period, and treatment $\times$ time. The statistical model used was:

$$
Y i j k=\mu+T i+H j+A k+P j+(T H) i j+e i j k l
$$

Where:

$Y i j k l=$ observation of the effect of treatment $i$ per hours of incubation (rate of degradation) or collection time (ruminal parameters) $j$ in animal $k ; \mu=$ overall mean; $T i=$ effect of treatment ( $i=1$ (Hay), 2 (CONT), 3 (MON), 4 (SALI), and 5 (FLAV);

$H j=$ effect of incubation hours for degradability $(j=1, \ldots ., 7)$ or collection times for ruminal parameters $(j=1, \ldots . ., 13)$;

$A k=$ animal effect $(k=1, \ldots, 5), P j=$ the period effect $(j=1, \ldots . ., 5)$;

$T H i j=$ interaction between treatment $i$ and time $j$; and $e i j k l=$ random error associated with each observation.

When significant $(P \leq 0.05)$ F-statistics were noted, means were separated using a multiple comparison test (Tukey's method) and treatment differences were considered significant at $P \leq 0.05$.

\section{Results}

The supply of concentrate with or without additives (CONT, MON, SALI, and FLAV) affected the intake $(P \leq 0.05)$ of DM, OM, and nutrients in $\mathrm{kg} \mathrm{day}^{-1}$ or $\mathrm{g} \mathrm{kg}^{-1}$ of BW when compared to the treatment HAY (Table 2). The animals of the HAY treatment showed higher $(P \leq 0.05) \mathrm{DM}$ and nutrients intake from hay, however, their total DM and total nutrient intake was lower $(P \leq 0.05)$ than those receiving the treatments with the concentrate. The inclusion of concentrate did not show a significant difference $(P>0.05)$ on total aNDFom and EE ( $\mathrm{g} \mathrm{kg}^{-1}$ of BW). No effects of the inclusion of MON, SALI, and FLAV in the diet was observed $(P>0.05)$ on the intake of hay DM, total DM, and nutrients in $\mathrm{kg} \mathrm{d}^{-1}$ or $\mathrm{g} \mathrm{kg}^{-1}$ of BW. The water intake increased $(P \leq 0.05)$ with the addition of concentrate in the diets, however, no effect was observed from the use of additives. 
Table 2: Effect of the inclusion of concentrate and antimicrobial growth promoters' additives in sheep diet on intake of DM, OM, CP, aNDFom, EE, NSC, and ashes of hay and total diet (hay + concentrate)

\begin{tabular}{|c|c|c|c|c|c|c|c|}
\hline \multirow{2}{*}{ Intake of ${ }^{1}$} & \multicolumn{5}{|c|}{ Treatments $^{2}$} & \multirow{2}{*}{ SEM } & \multirow{2}{*}{$P$-value } \\
\hline & HAY & CONT & MON & SALI & FLAV & & \\
\hline \multicolumn{8}{|l|}{$k g d a y^{-1}$} \\
\hline DM Hay & $1.01^{\mathrm{a}}$ & $0.68^{b}$ & $0.65^{\mathrm{b}}$ & $0.73^{b}$ & $0.65^{b}$ & 0.050 & 0.0018 \\
\hline DM Total & $1.01^{\mathrm{a}}$ & $1.56^{\mathrm{b}}$ & $1.57^{\mathrm{b}}$ & $1.62^{b}$ & $1.54^{\mathrm{b}}$ & 0.070 & 0.0004 \\
\hline OM Hay & $0.95^{\mathrm{a}}$ & $0.64^{\mathrm{b}}$ & $0.61^{\mathrm{b}}$ & $0.68^{\mathrm{b}}$ & $0.62^{b}$ & 0.047 & 0.0021 \\
\hline OM Total & $0.95^{\mathrm{a}}$ & $1.43^{\mathrm{b}}$ & $1.44^{\mathrm{b}}$ & $1.49^{\mathrm{b}}$ & $1.42^{\mathrm{b}}$ & 0.065 & 0.0005 \\
\hline CP Hay & $0.08^{\mathrm{a}}$ & $0.05^{\mathrm{b}}$ & $0.05^{\mathrm{b}}$ & $0.05^{\mathrm{b}}$ & $0.05^{\mathrm{b}}$ & 0.004 & 0.0006 \\
\hline CP Total & $0.08^{\mathrm{a}}$ & $0.22^{\mathrm{b}}$ & $0.22^{\mathrm{b}}$ & $0.22^{\mathrm{b}}$ & $0.22^{\mathrm{b}}$ & 0.008 & $\leq 0.0001$ \\
\hline aNDFom Hay & $0.74^{\mathrm{a}}$ & $0.49^{\mathrm{b}}$ & $0.47^{\mathrm{b}}$ & $0.53^{b}$ & $0.48^{\mathrm{b}}$ & 0.037 & 0.0023 \\
\hline aNDFom Total & 0.74 & 0.68 & 0.67 & 0.72 & 0.67 & 0.042 & 0.7163 \\
\hline EE Hay & 0.01 & 0.01 & 0.01 & 0.01 & 0.01 & 0.002 & 0.5565 \\
\hline EE Total & $0.01^{\mathrm{b}}$ & $0.03^{\mathrm{a}}$ & $0.03^{\mathrm{a}}$ & $0.03^{\mathrm{a}}$ & $0.03^{\mathrm{a}}$ & 0.002 & $\leq 0.0001$ \\
\hline NSC Hay & $0.12^{\mathrm{a}}$ & $0.08^{\mathrm{b}}$ & $0.08^{b}$ & $0.09^{b}$ & $0.08^{b}$ & 0.006 & 0.0053 \\
\hline NSC Total & $0.12^{\mathrm{a}}$ & $0.50^{\mathrm{b}}$ & $0.52^{\mathrm{b}}$ & $0.51^{\mathrm{b}}$ & $0.51^{\mathrm{b}}$ & 0.019 & $\leq 0.0001$ \\
\hline Ashes Hay & $0.06^{\mathrm{a}}$ & $0.04^{\mathrm{b}}$ & $0.04^{b}$ & $0.05^{\mathrm{b}}$ & $0.04^{b}$ & 0.003 & 0.0002 \\
\hline Ashes Total & $0.06^{\mathrm{a}}$ & $0.13^{b}$ & $0.13^{b}$ & $0.13^{b}$ & $0.13^{b}$ & 0.005 & $\leq 0.0001$ \\
\hline Water $\left(\mathrm{L} \mathrm{day}{ }^{-1}\right)$ & $2.44^{\mathrm{a}}$ & $3.74^{\mathrm{b}}$ & $4.03^{b}$ & $4.06^{b}$ & $3.86^{\mathrm{b}}$ & 0.192 & 0.0003 \\
\hline \multicolumn{8}{|l|}{$g \mathrm{~kg}^{-1}$ of $B W$} \\
\hline DM Hay & $19.23^{\mathrm{a}}$ & $13.44^{\mathrm{b}}$ & $12.45^{\mathrm{b}}$ & $14.69^{b}$ & $12.93^{\mathrm{b}}$ & 1.209 & 0.0150 \\
\hline DM Total & $19.23^{\mathrm{a}}$ & $30.80^{\mathrm{b}}$ & $29.83^{b}$ & $32.10^{\mathrm{b}}$ & $30.33^{b}$ & 1.223 & $\leq 0.0001$ \\
\hline OM Hay & $18.02^{\mathrm{a}}$ & $12.62^{\mathrm{b}}$ & $11.68^{\mathrm{b}}$ & $13.76^{\mathrm{b}}$ & $12.13^{\mathrm{b}}$ & 1.150 & 0.0168 \\
\hline OM Total & $18.02^{\mathrm{a}}$ & $28.30^{\mathrm{b}}$ & $27.38^{\mathrm{b}}$ & $29.49^{b}$ & $27.85^{\mathrm{b}}$ & 1.155 & 0.0001 \\
\hline CP Hay & $1.42^{\mathrm{a}}$ & $1.07^{\mathrm{b}}$ & $0.93^{\mathrm{b}}$ & $1.10^{\mathrm{b}}$ & $0.99^{\mathrm{b}}$ & 0.073 & 0.0056 \\
\hline CP Total & $1.42^{\mathrm{a}}$ & $4.33^{\mathrm{b}}$ & $4.2^{\mathrm{b}}$ & $4.37^{\mathrm{b}}$ & $4.27^{b}$ & 0.073 & $\leq 0.0001$ \\
\hline aNDFom Hay & $14.07^{\mathrm{a}}$ & $9.75^{\mathrm{b}}$ & $9.08^{\mathrm{b}}$ & $10.65^{\mathrm{b}}$ & $9.37^{b}$ & 0.905 & 0.0161 \\
\hline aNDFom Total & 14.07 & 13.46 & 12.79 & 14.37 & 13.05 & 0.915 & 0.7349 \\
\hline EE Hay & 0.30 & 0.21 & 0.21 & 0.25 & 0.18 & 0.024 & 0.0533 \\
\hline EE total & $0.30^{\mathrm{a}}$ & $0.61^{\mathrm{b}}$ & $0.62^{\mathrm{b}}$ & $0.66^{\mathrm{b}}$ & $0.59^{\mathrm{b}}$ & 0.028 & $\leq 0.0001$ \\
\hline NSC Hay & $2.23^{\mathrm{a}}$ & $1.59^{\mathrm{b}}$ & $1.45^{\mathrm{b}}$ & $1.76^{\mathrm{b}}$ & $1.58^{\mathrm{b}}$ & 0.164 & 0.0450 \\
\hline NSC Total & $2.23^{\mathrm{a}}$ & $9.89^{\mathrm{b}}$ & $9.77^{\mathrm{b}}$ & $10.08^{b}$ & $9.94^{\mathrm{b}}$ & 0.165 & $\leq 0.0001$ \\
\hline Ashes Hay & $1.22^{\mathrm{a}}$ & $0.83^{\mathrm{b}}$ & $0.78^{\mathrm{b}}$ & $0.94^{\mathrm{b}}$ & $0.80^{\mathrm{b}}$ & 0.063 & 0.0028 \\
\hline Ashes Total & $1.22^{\mathrm{a}}$ & $2.49^{\mathrm{b}}$ & $2.45^{\mathrm{b}}$ & $2.61^{b}$ & $2.48^{\mathrm{b}}$ & 0.070 & $\leq 0.0001$ \\
\hline \multicolumn{8}{|c|}{ Water $\left(\mathrm{ml} \mathrm{kg}^{-1}\right.$} \\
\hline of BW) & $45.35^{\mathrm{a}}$ & $74.77^{\mathrm{b}}$ & $76.11^{\mathrm{b}}$ & $80.06^{\mathrm{b}}$ & $76.37^{\mathrm{b}}$ & 3.166 & $\leq 0.001$ \\
\hline
\end{tabular}

${ }^{1} \mathrm{DM}=$ dry matter; $\mathrm{OM}=$ organic matter; $\mathrm{CP}=$ crude protein; aNDFom= neutral detergent fiber with amylase and corrected for ashes; $\mathrm{EE}=$ ethereal extract; NSC $=$ nonstructural carbohydrates (100- (Ashes + $\mathrm{CP}+$ aNDFom + EE; Sniffen et $\left.a l^{(10)}\right)$.

${ }^{2}$ Treatments: HAY (hay only), CONT (hay + concentrate), MON (hay + concentrate + monensin), SALI (hay + concentrate + salinomycin), FLAV (hay + concentrate + flavomycin).

${ }^{\mathrm{ab}}$ Means followed by different letters in the same row are significantly different (Tukey, $P \leq 0.05$ ). 
The treatments with concentrate showed higher $(P \leq 0.05) \mathrm{DM}, \mathrm{OM}, \mathrm{CP}, \mathrm{EE}$, and NSC digestibility when compared to the treatment HAY (Table 3$)$. No difference $(P>0.05)$ in aNDFom digestibility was observed resulting in an increase in total digestible nutrients (TDN). The inclusion of additives (MON, SALI, and FLAV) did not affect the digestibility of DM, OM, EE, aNDFom, NSC, EE, and TDN when compared to the CONT group $(P>0.05)$.

Table 3: Effect of the inclusion of concentrate and antimicrobial growth promoters' additives in sheep diet on the apparent digestibility coefficients of DM, OM, CP, EE, aFDNom, and NSC

\begin{tabular}{llllllll}
\hline \multirow{2}{*}{ Digestibility of } & \multicolumn{2}{l}{ Treatments $^{\mathbf{2}}$} & & & \multirow{2}{*}{ SEM } & \multirow{2}{*}{$\boldsymbol{P}$-value } \\
\cline { 2 - 7 } & HAY & CONT & MON & SALI & FLAV & & \\
\hline DM (fraction 0-1) & $0.54^{\mathrm{a}}$ & $0.67^{\mathrm{b}}$ & $0.67^{\mathrm{b}}$ & $0.64^{\mathrm{b}}$ & $0.66^{\mathrm{b}}$ & 0.028 & 0.0305 \\
Digestible amount & $\left(\mathrm{g} \mathrm{kg} \mathrm{DM}^{-1}\right)$ & & & & & \\
OM & $563.69^{\mathrm{a}}$ & $685.58^{\mathrm{b}}$ & $700.04^{\mathrm{b}}$ & $664.79^{\mathrm{b}}$ & $700.15^{\mathrm{b}}$ & 24.418 & 0.0142 \\
CP & $636.25^{\mathrm{a}}$ & $819.29^{\mathrm{b}}$ & $803.30^{\mathrm{b}}$ & $756.69^{\mathrm{b}}$ & $852.49^{\mathrm{b}}$ & 29.610 & 0.0036 \\
EE & $498.05^{\mathrm{a}}$ & $723.88^{\mathrm{b}}$ & $782.96^{\mathrm{b}}$ & $786.39^{\mathrm{b}}$ & $674.80^{\mathrm{b}}$ & 41.600 & 0.0027 \\
aNDFom & 530.03 & 420.43 & 416.17 & 438.04 & 427.30 & 49.845 & 0.2004 \\
NSC & $507.27^{\mathrm{a}}$ & $883.04^{\mathrm{b}}$ & $877.02^{\mathrm{b}}$ & $871.69^{\mathrm{b}}$ & $888.30^{\mathrm{b}}$ & 23.749 & $\leq 0.0001$ \\
TDN & $519.70^{\mathrm{a}}$ & $618.92^{\mathrm{b}}$ & $616.82^{\mathrm{b}}$ & $610.36^{\mathrm{b}}$ & $628.44^{\mathrm{b}}$ & 24.335 & 0.0197 \\
\hline
\end{tabular}

${ }^{1} \mathrm{DM}=$ dry matter; $\mathrm{OM}=$ organic matter; $\mathrm{C}=$ crude protein; aNDFom= neutral detergent fiber with amylase and corrected for ashes; $\mathrm{EE}=$ ethereal extract; $\mathrm{NSC}=$ nonstructutal carbohydrates $(100-($ Ashes $+\mathrm{CP}+$ aNDFom + EE; Sniffen et $\left.a l^{(10)}\right)$.

${ }^{2}$ Treatments: HAY (hay only), CONT (hay + concentrate), MON (hay + concentrate + monensin), SALI (hay + concentrate + salinomycin), FLAV (hay + concentrate + flavomycin).

${ }^{a b}$ Means followed by different letters in the same row are significantly different (Tukey, $P \leq 0.05$ ).

The in situ disappearance rates of DM (Figure 1A) and NDF (Figure 1B) of hay were influenced by the experimental treatments and incubation times $(P \leq 0.05)$. The in situ disappearance rates of DM and NDF at 3, 8, and $96 \mathrm{~h}$ of incubation did not show a significant difference between treatments. However, the treatment HAY only at 16, 24, 48 , and $72 \mathrm{~h}$ of incubation showed disappearance rates higher than those in treatments with the concentrate. Comparing the influence of additives in relation to the CONT group, no difference was observed in the disappearance rate of DM and NDF $(P>0.05)$. The HAY treatment presented potential DM and NDF degradation at $48 \mathrm{~h}$ of incubation. Conversely, this was observed in treatments with the concentrate at $72 \mathrm{~h}$. 
Figure 1: Disappearance of dry matter (DM) (figure A) and neutral detergent fiber (NDF) (figure B) of hay (expressed as a fraction of 0-1) in the rumen of sheep
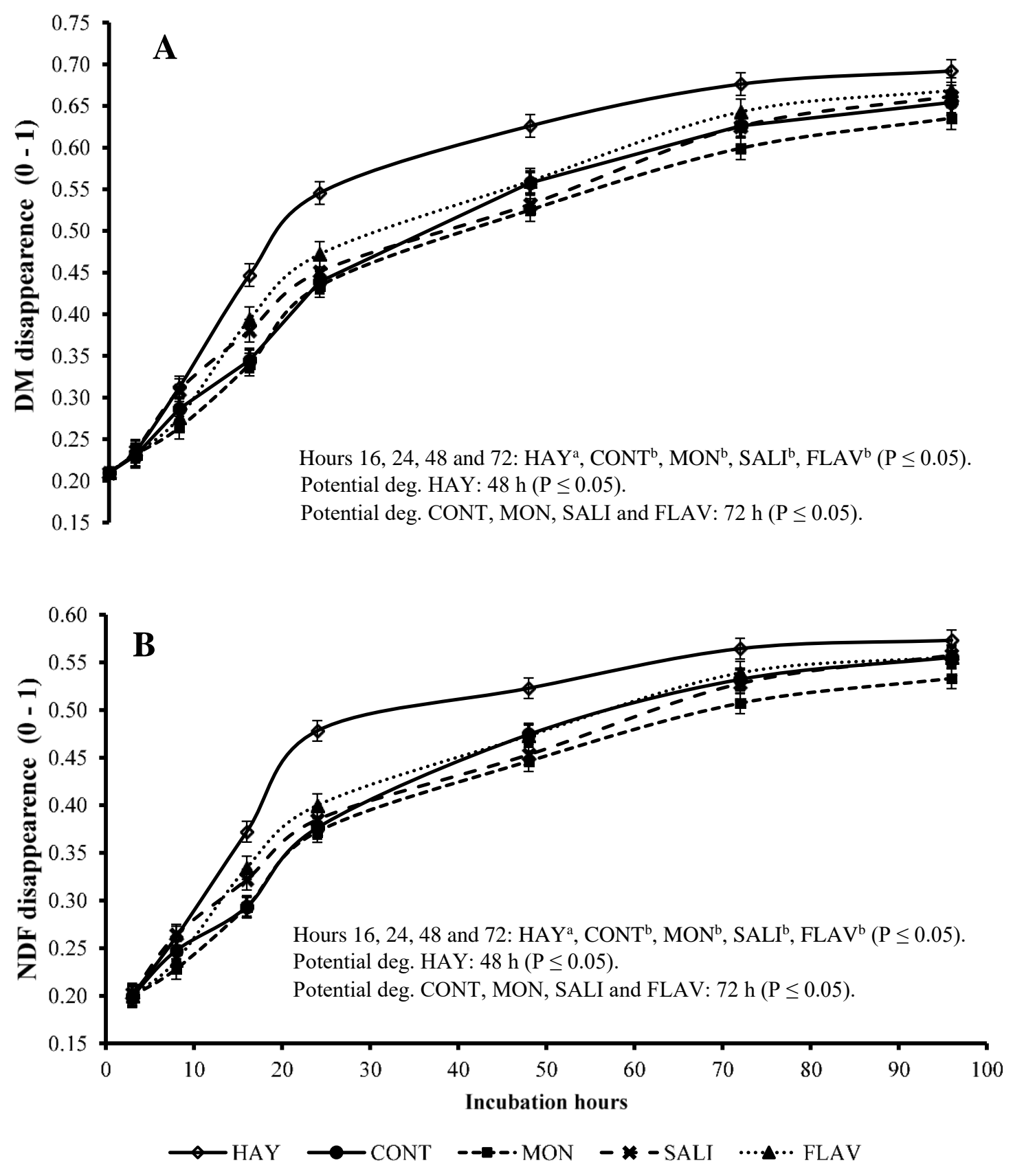

HAY (hay only), CONT (hay + concentrate), MON (hay + concentrate + monensin), SALI (hay + concentrate + salinomycin), FLAV (hay + concentrate + flavomycin). Vertical bars represent the standard deviation; Potential deg: represents the incubation time of hay needed to achieve potential degradation.

For the ruminal variables of hay DM degradation, the inclusion of concentrate in the diet reduced $(P \leq 0.05)$ the fraction "b" and the ED calculated at 0.02 and $0.05 \mathrm{~h}^{-1}$ and did not change $(P>0.05)$ the "c" fraction and the ED calculated at $0.08 \mathrm{~h}^{-1}$ (Table 4$)$. The inclusion of concentrate reduced $(P \leq 0.05)$ fraction "c" and the calculated ED (at 0.02, 0.05, and 
$\left.0.08 \mathrm{~h}^{-1} ; \mathrm{P} \leq 0.05\right)$ and did not change fraction " $\mathrm{b}$ " in the ruminal variables of Hay NDF degradation. The additives did not change these variables.

Table 4: Effect of the inclusion of concentrate and antimicrobial growth promoters' additives in sheep diet on the estimation of the ruminal parameters of DM and NDF degradation of hay (values are expressed as the fraction of 0-1)

\begin{tabular}{llllllll}
\hline \multirow{2}{*}{ Parameters $^{1}{ }^{2}$ Treatments $^{2}$} & & & & \multirow{2}{*}{ SEM } & P-value \\
\cline { 2 - 6 } HAY & CONT & MON & SALI & FLAV & & \\
\hline bM $(a=0.210)$ & & & & & & & \\
b & $0.482^{\mathrm{a}}$ & $0.445^{\mathrm{ab}}$ & $0.426^{\mathrm{b}}$ & $0.452^{\mathrm{ab}}$ & $0.454^{\mathrm{ab}}$ & 0.009 & 0.0112 \\
$\mathrm{c}$ & 0.055 & 0.050 & 0.035 & 0.034 & 0.039 & 0.008 & 0.2723 \\
ED $\left(0.02 \mathrm{~h}^{-1}\right)$ & $0.709^{\mathrm{a}}$ & $0.659^{\mathrm{ab}}$ & $0.613^{\mathrm{b}}$ & $0.625^{\mathrm{b}}$ & $0.653^{\mathrm{ab}}$ & 0.019 & 0.0146 \\
ED $\left(0.05 \mathrm{~h}^{-1}\right)$ & $0.565^{\mathrm{a}}$ & $0.521^{\mathrm{ab}}$ & $0.471^{\mathrm{b}}$ & $0.477^{\mathrm{b}}$ & $0.505^{\mathrm{ab}}$ & 0.020 & 0.0456 \\
ED $\left(0.08 \mathrm{~h}^{-1}\right)$ & 0.486 & 0.450 & 0.402 & 0.406 & 0.430 & 0.020 & 0.0679 \\
$N D F$ & & & & & & & \\
$\mathrm{~b}$ & 0.573 & 0.555 & 0.533 & 0.557 & 0.584 & 0.013 & 0.1810 \\
$\mathrm{c}$ & $0.048^{\mathrm{a}}$ & $0.033^{\mathrm{ab}}$ & $0.032^{\mathrm{ab}}$ & $0.028^{\mathrm{b}}$ & $0.032^{\mathrm{ab}}$ & 0.004 & 0.0289 \\
ED $\left(0.02 \mathrm{~h}^{-1}\right)$ & $0.401^{\mathrm{a}}$ & $0.347^{\mathrm{ab}}$ & $0.324^{\mathrm{b}}$ & $0.320^{\mathrm{b}}$ & $0.363^{\mathrm{ab}}$ & 0.017 & 0.0359 \\
$\mathrm{ED}\left(0.05 \mathrm{~h}^{-1}\right)$ & $0.277^{\mathrm{a}}$ & $0.223^{\mathrm{ab}}$ & $0.205^{\mathrm{b}}$ & $0.198^{\mathrm{b}}$ & $0.231^{\mathrm{ab}}$ & 0.015 & 0.0277 \\
ED $\left(0.08 \mathrm{~h}^{-1}\right)$ & $0.212^{\mathrm{a}}$ & $0.164^{\mathrm{ab}}$ & $0.150^{\mathrm{b}}$ & $0.143^{\mathrm{b}}$ & $0.169^{\mathrm{ab}}$ & 0.013 & 0.0252 \\
\hline
\end{tabular}

${ }^{1} \mathrm{DM}=$ dry matter; $\mathrm{a}=$ soluble fraction; $\mathrm{b}=$ insoluble fraction potentially degradable; $\mathrm{c}=$ degradation rate $(/ \mathrm{h}) ; \mathrm{ED}=$ effective degradation (considering a degradation rate of $0.02,0.05$, and $\left.0.08 \mathrm{~h}^{-1}\right), \mathrm{NDF}=$ neutral detergent fiber.

${ }^{2}$ Treatments: HAY (hay only), CONT (hay + concentrate), MON (hay + concentrate + monensin), SALI (hay + concentrate + salinomycin), FLAV (hay + concentrate + flavomycin).

${ }^{\mathrm{ab}}$ Means followed by different letters in the same row are significantly different (Tukey, $P \leq 0.05$ ).

Table 5 shows that the HAY treatment showed lower production $(P \leq 0.05)$ in $\mathrm{mmol} \mathrm{L}^{-1}$ of total acetate, propionate, butyrate, and total VFA and higher acetate:propionate ratio when compared to treatments with the concentrate (CONT, MON, SALI, and FLAV). When evaluated in mmol $100 \mathrm{mmol}^{-1}$, the HAY treatment showed a higher $(P \leq 0.05)$ proportion of acetate and lower $(P \leq 0.05)$ of propionate and butyrate when compared to treatments with the concentrate. 
Table 5: Effect of the inclusion of concentrate and antimicrobial growth promoters' additives in sheep diet on the production of short-chain fatty acids in the rumen

\begin{tabular}{|c|c|c|c|c|c|c|c|c|c|}
\hline \multirow{2}{*}{ Item } & \multicolumn{5}{|c|}{ Treatments $^{1}$} & \multirow{2}{*}{ SEM } & \multicolumn{3}{|c|}{$P$-value ${ }^{2}$} \\
\hline & HAY & CONT & MON & SALI & FLAV & & Treat & $\mathbf{h}$ & Treat $\times h$ \\
\hline \multicolumn{10}{|l|}{ Fatty acids (mmol $\left.L^{-1}\right)$} \\
\hline Acetate & $78.30^{\mathrm{b}}$ & $90.15^{\mathrm{a}}$ & $84.80^{\mathrm{a}}$ & $90.90^{\mathrm{a}}$ & $89.93^{\mathrm{a}}$ & 2.083 & $\leq 0.001$ & $\leq 0.001$ & 0.4278 \\
\hline Propionate & $12.25^{\mathrm{d}}$ & $21.37^{\mathrm{c}}$ & $24.98^{\mathrm{a}}$ & $24.14^{\mathrm{ab}}$ & $21.43^{\mathrm{bc}}$ & 0.759 & $\leq 0.001$ & 0.0002 & 0.9995 \\
\hline Butyrate & $4.09^{\mathrm{d}}$ & $10.64^{\mathrm{b}}$ & $9.15^{\mathrm{c}}$ & $9.49^{\mathrm{bc}}$ & $12.08^{\mathrm{a}}$ & 0.333 & $\leq 0.001$ & 0.0262 & 0.9840 \\
\hline Total VFA & $94.64^{\mathrm{b}}$ & $122.16^{\mathrm{a}}$ & $118.93^{\mathrm{a}}$ & $124.53^{\mathrm{a}}$ & $123.44^{\mathrm{a}}$ & 2.776 & $\leq 0.001$ & $\leq 0.001$ & 0.6340 \\
\hline Acetate:propionate ratio & $6.39^{\mathrm{a}}$ & $4.21^{\mathrm{b}}$ & $3.39^{\mathrm{c}}$ & $3.77^{\mathrm{b}}$ & $4.19^{\mathrm{b}}$ & 0.120 & $\leq 0.001$ & 0.6263 & 0.9993 \\
\hline \multicolumn{10}{|c|}{ 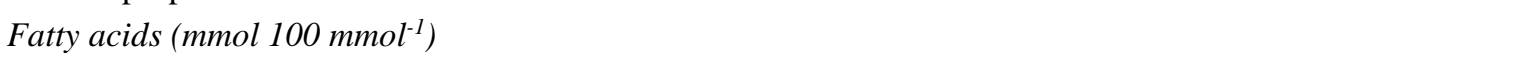 } \\
\hline Acetate & $82.61^{\mathrm{a}}$ & $73.94^{\mathrm{b}}$ & $71.26^{\mathrm{c}}$ & $73.15^{\mathrm{b}}$ & $73.02^{\mathrm{bc}}$ & 0.478 & $\leq 0.001$ & 0.9540 & 0.9992 \\
\hline Propionate & $13.06^{\mathrm{d}}$ & $17.35^{\mathrm{c}}$ & $21.01^{\mathrm{a}}$ & $19.14^{\mathrm{b}}$ & $17.36^{\mathrm{c}}$ & 0.422 & $\leq 0.001$ & 0.6102 & 1.0000 \\
\hline Butyrate & $4.32^{\mathrm{d}}$ & $8.7^{\mathrm{b}}$ & $7.73^{\mathrm{c}}$ & $7.71^{\mathrm{c}}$ & $9.62^{\mathrm{a}}$ & 0.264 & $\leq 0.001$ & 0.6895 & 0.9996 \\
\hline
\end{tabular}

${ }^{1}$ Treatments: HAY (hay only), CONT (hay + concentrate), MON (hay + concentrate + monensin), SALI (hay + concentrate + salinomycin), FLAV (hay + concentrate + flavomycin).

${ }^{2}$ Treat $=$ treatment.

${ }^{\text {ab }}$ Means followed by different letters in the same row are significantly different (Tukey, $P \leq 0.05$ ).

Analyzing the effects of the additives (MON, SALI and FLAV) in relation to the CONT in $\mathrm{mmol} \mathrm{L}^{-1}$, the acetate production was not altered $(P>0.05)$. MON and SALI increased $(P \leq 0.05)$ the propionate production in relation to that in the CONT and FLAV did not differ from these. FLAV induced the highest $(P \leq 0.05)$ production of butyrate, MON the lowest $(P \leq 0.05)$, and SALI did not differ from the CONT and MON. The total VFA production of the additives did not differ from the CONT. The acetate:propionate ratio was the smallest $(P \leq 0.05)$ in the MON treatment compared to the other treatments. When evaluated in mmol $100 \mathrm{mmol}^{-1}$, the MON presented lower $(P \leq 0.05)$ acetate production than CONT and SALI, but did not differ from FLAV. The CONT, SALI and FLAV groups did not differ. The highest $(P \leq 0.05)$ proportion of propionate was produced in the MON treatment, followed by the SALI, FLAV, and CONT. The latter two did not differ. The highest $(P \leq 0.05)$ proportion of butyrate was observed in the FLAV treatment followed by the CONT, MON and SALI. The latter two did not differ.

The inclusion of concentrate in the diets reduced $(P \leq 0.05)$ the ruminal $\mathrm{pH}$ in relation to the HAY treatment (Figure 2A) at all evaluated time points. No difference in $\mathrm{pH}$ was observed as the result of additives. The use of the concentrate caused a high $\mathrm{pH}$ variation throughout the day, with maximum values of 6.46 and minimum of 5.68. The lowest values were observed between 2 and $4 \mathrm{~h}$ after feeding.

The inclusion of concentrate in the diet increased $(P \leq 0.05)$ the production of $\mathrm{N}^{-N_{3}}$ in relation to the HAY treatment at all evaluated time points (Figure 2B). MON was the only additive showing some effect $(P \leq 0.05)$ compared to the CONT treatment by reducing the $\mathrm{N}-\mathrm{NH}_{3}$ concentration only at four hours after the morning feeding. No effect of the other additives was observed for this variable. 
Figure 2: Mean values of $\mathrm{pH}$ (Figure A) and ammoniacal nitrogen $\left(\mathrm{NH}_{3}-\mathrm{N}\right.$; Figure B) in the rumen of sheep at different collection times
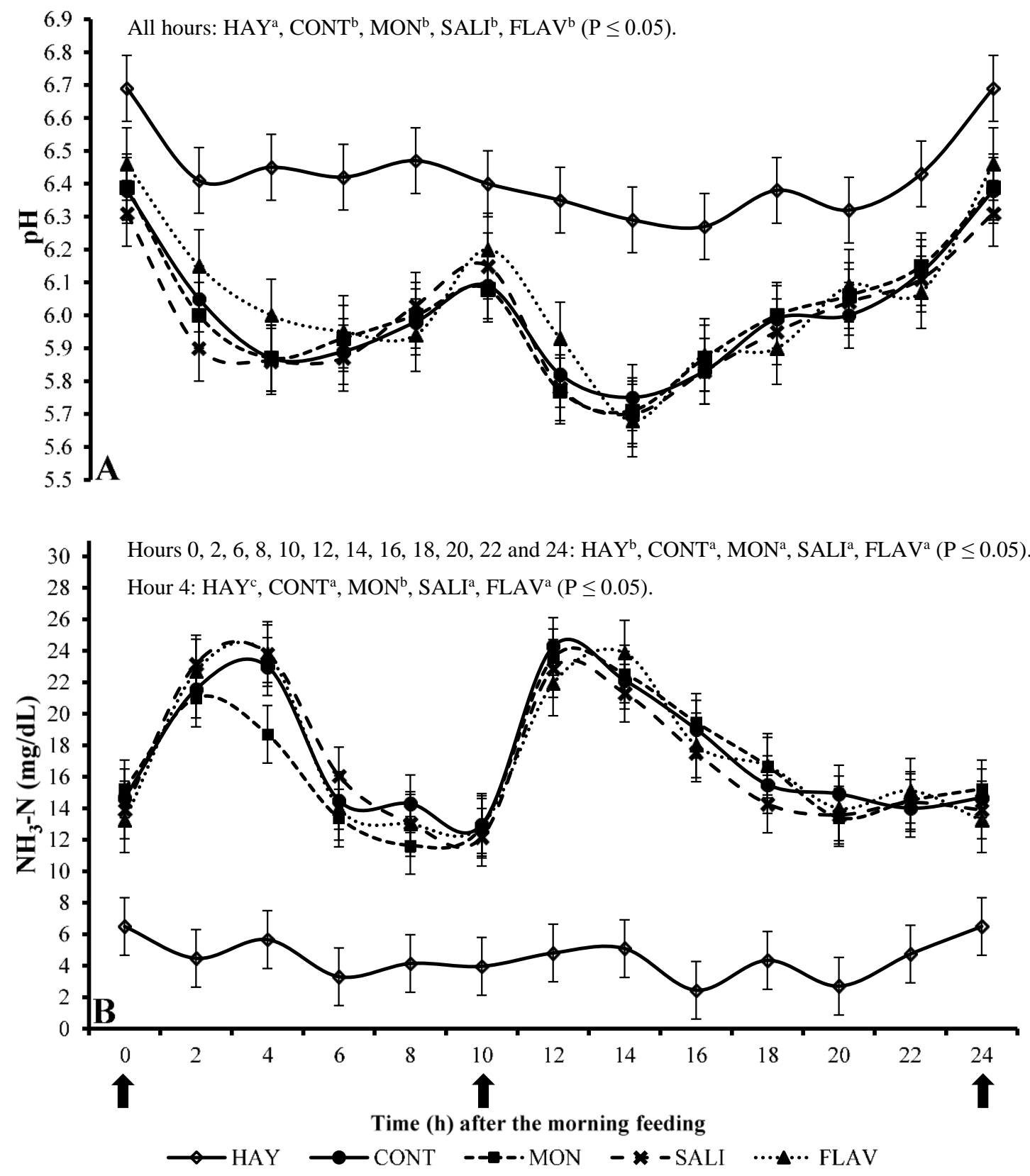

HAY (hay only), CONT (hay + concentrate), MON (hay + concentrate + monensin), SALI (hay + concentrate + salinomycin), FLAV (hay + concentrate + flavomycin). Vertical bars represent the standard deviation 
The use of the concentrate increased $(P \leq 0.05)$ nitrogen intake (Table 6) despite the fecal and urine losses, the amount absorbed and retained was higher $(P \leq 0.05)$ than that observed in the HAY treatment. No significant difference was observed in nitrogen intake with the use of additives.

Table 6: Effect of the inclusion of concentrate and antimicrobial growth promoters' additives in sheep diet on nitrogen balance

\begin{tabular}{|c|c|c|c|c|c|c|c|}
\hline \multirow{2}{*}{ Intake of } & \multicolumn{5}{|c|}{ Treatments $^{1}$} & \multirow{2}{*}{ SEM } & \multirow{2}{*}{$P$-value } \\
\hline & $\overline{\text { HAY }}$ & CONT & MON & SALI & FLAV & & \\
\hline \multicolumn{8}{|l|}{$g$ day $^{-1}$} \\
\hline $\mathrm{N}$ intake - hay & $12.18^{\mathrm{a}}$ & $8.67^{\mathrm{b}}$ & $7.72^{\mathrm{b}}$ & $8.79^{b}$ & $7.98^{\mathrm{b}}$ & 0.458 & 0.0001 \\
\hline \multirow[b]{2}{*}{ concentrate } & - & & & & & & \\
\hline & $0.00^{\mathrm{a}}$ & $26.57^{\mathrm{b}}$ & $27.76^{\mathrm{b}}$ & $26.73^{b}$ & $27.32^{\mathrm{b}}$ & 1.153 & $\leq 0.0001$ \\
\hline $\mathrm{N}$ intake - total & $12.18^{\mathrm{a}}$ & $35.24^{\mathrm{b}}$ & $35.48^{\mathrm{b}}$ & $35.51^{\mathrm{b}}$ & $35.30^{\mathrm{b}}$ & 1.193 & $\leq 0.0001$ \\
\hline $\mathrm{N}$ fecal & $3.50^{\mathrm{a}}$ & $6.34^{\mathrm{b}}$ & $5.92^{\mathrm{b}}$ & $7.01^{\mathrm{b}}$ & $6.41^{\mathrm{b}}$ & 0.550 & 0.0072 \\
\hline $\mathrm{N}$ absorbed & $8.68^{\mathrm{a}}$ & $28.91^{b}$ & $29.56^{\mathrm{b}}$ & $28.50^{\mathrm{b}}$ & $29.22^{\mathrm{b}}$ & 0.838 & $\leq 0.0001$ \\
\hline $\mathrm{N}$ urinary & $3.04^{\mathrm{a}}$ & $11.11^{\mathrm{b}}$ & $14.42^{\mathrm{b}}$ & $12.13^{b}$ & $12.51^{\mathrm{b}}$ & 1.181 & $\leq 0.0001$ \\
\hline $\mathrm{N}$ fecal + urinary & $6.54^{\mathrm{a}}$ & $17.45^{\mathrm{b}}$ & $20.34^{\mathrm{b}}$ & $19.15^{\mathrm{b}}$ & $18.59^{\mathrm{b}}$ & 1.459 & 0.0001 \\
\hline \multirow{2}{*}{ 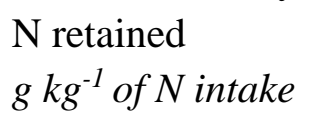 } & $5.65^{\mathrm{a}}$ & $17.80^{\mathrm{b}}$ & $15.14^{\mathrm{b}}$ & $16.37^{\mathrm{b}}$ & $16.70^{\mathrm{b}}$ & 1.444 & $\leq 0.0001$ \\
\hline & 706.22 & 818.70 & 833.60 & 803.72 & 825.92 & 20.96 & \\
\hline \multirow[t]{2}{*}{$\mathrm{N}$ absorbed } & a & $\mathrm{b}$ & $\mathrm{b}$ & $\mathrm{b}$ & $\mathrm{b}$ & \multicolumn{2}{|c|}{70.0060} \\
\hline & & & & & & 52.69 & \\
\hline $\begin{array}{l}\mathrm{N} \text { retained } \\
g \mathrm{~kg}^{-1} \text { of } B W\end{array}$ & 454.82 & 501.56 & 428.58 & 468.36 & 471.22 & & 0.7101 \\
\hline $\mathrm{N}$ intake - hay & $0.23^{\mathrm{a}}$ & $0.17^{\mathrm{b}}$ & $0.15^{\mathrm{b}}$ & $0.18^{b}$ & $0.16^{\mathrm{b}}$ & 0.011 & 0.0200 \\
\hline \multicolumn{8}{|l|}{$\mathrm{N} \quad$ intake } \\
\hline concentrate & $0.00^{\mathrm{a}}$ & $0.52^{\mathrm{b}}$ & $0.52^{b}$ & $0.52^{b}$ & $0.52^{b}$ & 0.002 & $\leq 0.0001$ \\
\hline $\mathrm{N}$ intake - total & $0.23^{\mathrm{a}}$ & $0.69^{b}$ & $0.67^{\mathrm{b}}$ & $0.70^{\mathrm{b}}$ & $0.68^{\mathrm{b}}$ & 0.011 & $\leq 0.0001$ \\
\hline $\mathrm{N}$ fecal & $0.07^{\mathrm{a}}$ & $0.13^{\mathrm{b}}$ & $0.11^{\mathrm{b}}$ & $0.14^{\mathrm{b}}$ & $0.12^{\mathrm{b}}$ & 0.009 & 0.0012 \\
\hline $\mathrm{N}$ absorbed & $0.16^{\mathrm{a}}$ & $0.57^{\mathrm{b}}$ & $0.56^{\mathrm{b}}$ & $0.56^{\mathrm{b}}$ & $0.56^{\mathrm{b}}$ & 0.010 & $\leq 0.0001$ \\
\hline $\mathrm{N}$ urinary & $0.06^{\mathrm{a}}$ & $0.22^{\mathrm{b}}$ & $0.27^{\mathrm{b}}$ & $0.23^{\mathrm{b}}$ & $0.24^{\mathrm{b}}$ & 0.016 & $\leq 0.0001$ \\
\hline $\mathrm{N}$ fecal + urinary & $0.13^{\mathrm{a}}$ & $0.35^{\mathrm{b}}$ & $0.38^{\mathrm{b}}$ & $0.37^{\mathrm{b}}$ & $0.36^{\mathrm{b}}$ & 0.019 & $\leq 0.0001$ \\
\hline $\mathrm{N}$ retained & $0.10^{\mathrm{a}}$ & $0.35^{\mathrm{b}}$ & $0.29^{b}$ & $0.33^{\mathrm{b}}$ & $0.32^{\mathrm{b}}$ & 0.020 & $\leq 0.0001$ \\
\hline
\end{tabular}

${ }^{1}$ Treatments: HAY (hay only), CONT (hay + concentrate), MON (hay + concentrate + monensin), SALI (hay + concentrate + salinomycin), FLAV (hay + concentrate + flavomycin).

${ }^{\mathrm{ab}}$ Means followed by different letters in the same row are significantly different (Tukey, $P \leq 0.05$ ). 


\section{Discussion}

\section{Effect of concetrate}

The inclusion of concentrate in the diet, increased the intake of MS and nutrients (Table 2). The lowest intake observed in the HAY treatment, could be the result of a ruminal physical limitation in sheep. The hay intake may have caused greater filling and ruminal distension that, according to Grovum ${ }^{(16)}$, provoke inhibitory neural stimulus from the hunger center reducing feed intake. The addition of concentrate, is known to increase the passage rate, providing limiting nutrients, such as nitrogen and sulfur, to ruminal microorganisms and leading to a high rate of multiplication of microorganism ${ }^{(17)}$ and consequently reflecting increased intake.

The inclusion of concentrate in the diet, increased the digestibility of DM and other nutrients (with the exception of aNDFom). According to Hagos and Melaku ${ }^{(18)}$, the lowest concentration of $\mathrm{CP}$ and highest of aNDFom in the HAY treatment may have reflected low microbial efficiency, leading to a low level of nutrients' fermentation and consequently lower digestibility.

The absence of improvement in the aNDFom digestibility as well as the reduction in the degradability of DM and NDF by the inclusion of concentrate may have occurred because the inclusion of rapidly fermentable carbohydrates, leads to a reduction in ruminal $\mathrm{pH}$, and increased development of amylolytic, and decreased development of cellulolytic bacteria $^{(19,20)}$. These microbial alterations reduce the production of fibrolytic enzymes and consequently negatively affect fiber degradability and digestibility.

The inclusion of concentrate in the diet increased the total production of VFA and proportions of propionate and butyrate, and a reduction in the acetate proportion and acetate:propionate ratio. The alteration in the VFA production with the inclusion of concentrate in the diet was probably the result of changes in the microbial population of the rumen, which is altered according to the type of substrate available. According to Wanapat and Khampa ${ }^{(20)}$, the inclusion of concentrate in the diet, increases the number of protozoa and amylolytic and proteolytic bacteria, and reduces the number of fungi and cellulolytic bacteria. These alterations cause changes in the type and quantity of VFA produced.

The lowest ruminal $\mathrm{pH}$ was observed in treatments containing concentrate. Rumen microorganisms ferment carbohydrates producing VFA and lactate, which have an acidogenic effect. Therefore, the inclusion of rapidly fermentable carbohydrates in the diet increases the fermentation rate and production of these compounds, reducing the $\mathrm{pH}^{(3,17)}$. In addition, the inclusion of the concentrate is usually associated with less 
rumination and chewing with the consequent low production of saliva and diet buffer capacity $^{(19,21)}$. The treatment HAY, showed a low daily $\mathrm{pH}$ variation because the animals showed gradual intake throughout the day. Conversely, the treatments with the concentrate, presented a high $\mathrm{pH}$ variation during the day because the supplied concentrate was quickly consumed, reflecting subsequent drops in $\mathrm{pH}$ values, with the smallest values observed between 2 and $4 \mathrm{~h}$ after the feeding. The lowest $\mathrm{pH}$ values of 5.68 and 6.27 were observed in the treatments with the concentrate and hay, respectively. According to Hoover and Stokes ${ }^{(22)}$, these values are within the range suitable for maximum microbial growth and maximal ruminal digestion of fibers (5.5 to 7.0) and the great $\mathrm{pH}$ range for fiber digestion is from 6.7 to 7.1 .

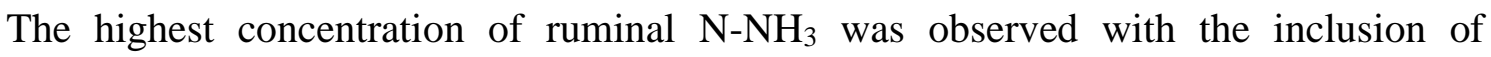
concentrate. According to Van Soest ${ }^{(19)}$, protein degradation in the rumen occurs through the action of enzymes secreted by ruminal microorganisms. These bacteria digest part of the protein, and others microorganisms on site use amino acids, peptides, and ammonia for cell multiplication. When the rate of ammonia production is greater than the rate of use, it is absorbed by the animal through the rumen wall passing into the blood stream and converting into urea in the liver. Urea can be recycled or lost through the urine. Excessive values are reached by a high inclusion of concentrate in the diets and are not desired.

The treatment HAY presented a low daily variation of $\mathrm{N}^{-\mathrm{NH}_{3}}$ (Figure $2 \mathrm{~B}$ ) because the animals gradually consumed the feed throughout the day. On the other hand, as observed in the $\mathrm{pH}$ analysis, the treatments with concentrate showed a high variation due to the fast intake of concentrate causing peaks of ammonia production between 2 and $4 \mathrm{~h}$ after feeding. These increased levels occurred as the result of high amounts of CP from the concentrate $\left(188 \mathrm{~g} \mathrm{~kg}^{-1}\right)$, increasing its rumen degradation rate and producing $\mathrm{N}-\mathrm{NH}_{3}$ peaks.

There was an increase in the amount of absorbed and retained $\mathrm{N}$ ( $\mathrm{g} \mathrm{d}^{1}$ or $\mathrm{g} \mathrm{kg}^{-1}$ of CP) with the inclusion of the concentrate in the diet. This happened probably due to the high $\mathrm{N}$ intake and high $\mathrm{N}$ digestibility contained in the concentrate compared to those in HAY. However, when the amount of $\mathrm{N}$ retained in $\mathrm{g} \mathrm{kg}^{-1}$ of the $\mathrm{N}$ ingested was analyzed, the absence of increased efficiency in the use of ingested $\mathrm{N}$ with the inclusion of concentrate was probably resulting from the low flow rate displayed in the HAY treatment, which improved the efficiency of $\mathrm{N}$ use, producing results similar to those in the concentrate treatments. The inclusion of concentrate resulted in high losses of $\mathrm{N}$, mainly through urine. This may have been due to a low efficiency of the urea cycle, which is a reflection

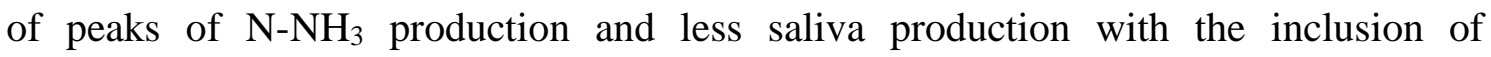
concentrate $^{(19)}$. Because the inclusion of concentrate reflects less chewing and rumination time $^{(21)}$, less saliva is produced, and less nitrogen is recycled in this way, which ends up being eliminated in the urine. 


\section{Effect of additives}

The inclusion of additives did not alter the DM and nutrients intake. However, ionophores are known to have an effect on DM ingestion leading to reduced intake when used in diets with a high proportion of concentrate ${ }^{(23,24)}$. This effect may occur as a consequence of an increase in the concentration of ruminal propionic acid, which reflects an increase in energy efficiency, allowing nutritional requirements to be reached with a smaller amount of feed intake ${ }^{(7)}$. This intake is also affected by pathophysiological aspects such as ruminal $\mathrm{pH}$. Thus, a diet that induces rumen acidosis, with the addition of ionophores, may lead to a smaller $\mathrm{pH}$ drop, increasing intake ${ }^{(25)}$. However, in this experiment, besides the high hay intake (approximately $430 \mathrm{~g} \mathrm{~kg}^{-1}$ of the diet), the diets were all cationic, which produces an alkalizing effect that may have caused the lack of effects of additives on the intake.

The inclusion of additives did not alter the digestibility of the diet. However, ionophores can increase dietary digestibility by increasing the DM retention time in the rumen as the result of lower voluntary intake, stimulating rumination, improving the ruminal environment, and allowing increased digestibility ${ }^{(26)}$. However, this effect was not observed in this study because the additives did not alter the intake.

The additives did not influence the degradability of hay. Ionophores are known to alter the microbial population of the rumen and act on cellulolytic bacteria, which can lead to a reduction in fiber degradability ${ }^{(27)}$. Nevertheless, it is probably easier to observe these effects in diets with higher proportions of roughage. Edward et al ${ }^{(5)}$ report in an in vitro experiment that cellulolytic Gram-negative bacteria of the genus Fibrobacter are among the most sensitive to the action of flavomycin. According to these same authors, flavomycin normally does not decrease fiber degradation in in vitro and in vivo studies. Therefore, it is probable that the cellulolytic activities of bacteria of the genus Ruminococcus, fungi, and protozoa, which are not affected by this antibiotic and are in the microorganism's rumen population, compensate decreased numbers of Fibrobacter bacteria that could affect fiber degradation.

The additives altered the production of VFA. Ionophores cause such alterations in the production of VFAs by modifying bacterial populations of the rumen. Gram-positive bacteria that produce acetate, butyrate, and $\mathrm{H}_{2}$ are inhibited by ionophores, and Gramnegative bacteria that produce propionate find better conditions to reproduce ${ }^{(28)}$. The production of butyrate was increased in FLAV. (Thus, the response from the effect of flavomycin on the proportion of VFA differs from that from ionophores, which promotes an increase in the proportion of propionate. The action of flavomycin, not exactly on the same microorganisms, possibly reflects these alterations.

The additives did not alter the ruminal $\mathrm{pH}$. This happened probably due to the high proportion of hay in the diet (approximately $430 \mathrm{~g} \mathrm{~kg}^{-1}$ diet) inducing longer intake time, 
regurgitation, and saliva production resulting in a small drop in ruminal $\mathrm{pH}$ and not allowing the demonstration of these antibiotics' effects.

The reduction in the concentration of $\mathrm{N}^{-\mathrm{NH}_{3}}$ during the first peak of production (only 4 $\mathrm{h}$ after the morning feeding) was only detected in the diet with MON. This response is associated with the reduction in the number of bacteria that use amino acids and peptides as an energy source for their growth, and consequently, release ammonia in the ruminal environment. This reduction in the use of amino acids and peptides favors their passage into the small intestine and absorption, increasing the efficiency in the use of nitrogen ${ }^{(29)}$.

No effect was observed from additives on nitrogen balance. Nevertheless, the ionophores may promote an improved utilization of dietary nitrogen, as a result of reduced DM intake, consequent reduction of nitrogen intake, and reduced rumen deamination ${ }^{(30)}$. In this study, the use of additives did not alter DM intake, and salinomycin and flavomycin did not alter the concentration of $\mathrm{N}_{-} \mathrm{NH}_{3}$. Therefore, the absence of an effect on the total nitrogen balance was expected. Although MON reduced the ammonia peak production after the morning feeding, this was not enough to alter the nitrogen balance.

\section{Conclusions and implications}

The addition of concentrate to the sheep diet caused alterations in the intake, digestibility, ruminal variables (VFA, $\mathrm{pH}$, and $\mathrm{N}-\mathrm{NH}_{3}$ ), and nitrogen balance. MON, SALI, and FLAV altered the production of VFA, however, only MON reduced the production of $\mathrm{N}^{-\mathrm{NH}_{3}}$. Among the tested additives, monensina caused the most beneficial changes in the ruminal metabolism of sheep.

\section{Acknowledgements}

The authors would like to thank the company Nutract Agrisolutions (Chapecó, SC, Brazil) for partially funding this research and also the Coordenação de Aperfeiçoamento de Pessoal de Nivel Superior (Capes) for the scholarship provided to the first author.

\section{Literature cited:}

1. NRC. Nutrient requirements of small ruminants: Sheep, goats, cervids, and new world camelids. 1st ed. Washington, DC: National Academy Press; 2007. 
2. Ma T, Deng, KD, Tu Y, et al. Effect of dietary forage-to-concentrate ratios on urinary excretion of purine derivatives and microbial nitrogen yields in the rumen of Dorper crossbred sheep. Livestock Sci 2014;160:37-44.

3. Owens FN, Secrist DS, Hill WJ, Gill DR. Acidosis in cattle: a review. J Anim Sci 1998;76:275-86.

4. Nagaraja TG, Newbold CJ, Van Nevel CJ, Demeyer DI. Manipulation of ruminal fermentation. In: Hobson PN, editor. The Rumen Microbial Ecosystem. New York: Blackie; 1997:523-632.

5. Edwards JE, Mcewan NR, Mckain N, Walker N, Wallace RJ. Influence of flavomycin on ruminal fermentations and microbial populations in sheep. J Microbiol 2005;151:717-25.

6. Pressman BC. Biological applications of ionophores. Ann Rev Biochem 1976;45:501503.

7. Russel JB, Strobel HJ. Effect of ionophores on ruminal fermentation. J Appl Environ Microbiol 1989;55:1-6.

8. Murray PJ, Winslow SG, Rowe JB. Conditions under which flavomycin increases wool growth and liveweight gain in sheep. Aust J Agric Res 1992;43:367-87.

9. Bretschneider G, Elizalde JC, Pérez FA. The effect of feeding antibiotic growth promoters on the performance of beef cattle consuming forage-based diets: A review. Livestock Sci 2008;114:135-49.

10. Sniffen CJ, Connor JD, Van Soest P. A net carbohydrate and protein system for evalution cattle diets. II. Carboydrate and protein availability. J Anim Sci 1992;70:3562-77.

11. Ørskov ER, McDonald I. The estimation of protein degradability in the rumen from incubation measurements weighted according to rate of passage. J Agric Sci 1979;92:499-503.

12. Latimer GW; AOAC International. Association of Official Analytical Chemistry. Official methods of analysis. 15th ed. Arlington, VA: AOAC International; 1990.

13. Van Soest PJ, Robertson JB, Lewis BA. Methods for dietary fiber, neutral detergent fiber, and non starch polyssacarides in relation to animal nutrition. J Dairy Sci 1991;74:3583-97.

14. Ribeiro SS, Vasconcelos JT, Morais MG, Ítavo CBCF, Franco GL. Effects of ruminal infusion of a slow-release polymer-coated urea or conventional urea on apparent nutrient digestibility, in situ degradability, and rumen parameters in cattle fed lowquality hay. Anim Feed Sci Technol 2011;164:53-61. 
15. Erwin ES, Marco GJ, Emery EM. Volatile fatty acid analyses of blood and rumen fluid by gas chromatography. J Dairy Sci 1961;44:1768-71.

16. Grovum WL. Apetito, sapidez y control del consumo de alimentos. In: Church DC, editor. El rumiante. Fisiología digestiva y nutrición. ed. Acríbia, Zaragoza; 1988:225-242.

17. Dixon RM, Stockdale CR. Associative effects between forages and grains: consequences for feed utilization. Aust J Agric Res 1999;50:757-73.

18. Hagos T, Melaku S. Feed intake, digestibility, body weight and carcass parameters of Afar rams fed tef (Eragrostistef) straw supplemented with graded levels of concentrate mix. Trop Anim Health Prod 2009;41:599-606.

19. Van Soest PJ. Nutritional ecology of the ruminant, 2nd ed. Ithaca, NY, USA: Comstock Publishing Association; 1994.

20. Wanapat M, Khampa S. Effect of levels of supplementation of concentrate containing high levels of cassava chip on rumen ecology, microbial $\mathrm{n}$ supply and digestibility of nutrients in beef cattle. AJAS 2007;20:75-81.

21. Kleefisch MT, Zebeli Q, Humer E, Kröger I, Ertl P, Klevenhusen, F. Effects of the replacement of concentrate and fibre-rich hay by high-quality hay on chewing, rumination and nutrient digestibility in non-lactating Holstein cows. Arch Anim Nutr 2016;71:21-36

22. Hoover WH, Stokes SR. Balancing carbohydrates and proteins for optimum rumen microbial yield. J Dairy Sci 1991;74:3630-44.

23. Gastaldello Jr AL, Pires AV, Susin I, et al. Limestone with different particle size and sodium bicarbonate to feedlot lambs fed high grain diets with or without monensin. Small Ruminant Res 2013;114:80-5.

24. Mirzaei-Alamouti H, Moradi S, Shahalizadeh Z, et al. Both monensin and plant extract alter ruminal fermentation in sheep but only monensin affects the expression of genes involved in acid-base transport of the ruminal epithelium. Anim Feed Sci Technol 2016;219:132-43.

25. Rodrigues PHM, Mattos WRS, Melotti L, Rodrigues RR. Monensin and total tract digestibility in wethers fed different roughage/concentrate ratios. Sci Agric 2001;58:449-55.

26. Ellis WC, Horn GW, Delaney D, Pond KR. Effects of ionophores on grazed forage utilization and their economic value for cattle on wheat pasture. In: National wheat pasture symposium1983; Stillwater, USA. Stillwater: Agricultural Experimental Station; 1983. 
27. Bogaert C, Gomez L. Jouany JP. Effects of lasalocid and cationomycin on the digestion of plant cell walls in sheep. Can J Anim Sci 1991;71:379-88.

28. Bergen WG, Bates DB. Ionophores: Their effect on production efficiency and mode of action. J Anim Sci 1984;58:1465-83.

29. Yang CMJ, Russell JB. The effect of monensin supplementation on ruminal ammonia accumulation in vivo and the numbers of amino acid-fermenting bacteria. J Anim Sci 1993;71:3470-6.

30. Mcguffey RK, Richardson LF, Wilkinson JID. Ionophores for dairy cattle: current status and future outlook. J Dairy Sci 2001;84:194-203. 